\title{
THE SOCIO-ECONOMIC IMPACT OF THE TABLE Mountain National Park
}

\author{
Melville Saayman* \\ North-West University \\ melville.saayman@nwu.ac.za
}

\author{
Andrea Saayman\# \\ North-West University \\ andrea.saayman@nwu.ac.za
}

Received: August 2012

\author{
Riaan Rossouw+ \\ North-West University \\ riaan.rossouw@nwu.ac.za
}

Accepted: November 2012

\begin{abstract}
This article will determine the socio-economic impact of South Africa's largest urban national park, and the one that attracts the most visitors. Because national parks have more functions than mere conservation, the following questions arise: "What economic and social impacts are created by such parks?" and "How do communities benefit from allocating land for conservation?" Little research on this topic has been conducted in Southern Africa, and this research therefore contributes to our knowledge. Two surveys were conducted. One focused on the communities surrounding the park and the other on visitors to the park. A Social Accounting Matrix (SAM) determined the economic value. Results showed that, although the park attracts the most visitors, it does not generate the greatest income when compared to other national parks. Results concerning the community survey revealed that the surrounding communities have very positive perceptions, although they believe the impacts to be more economic than social. Problem areas were also identified.
\end{abstract}

Keywords:

Conservation Tourism, Social Accounting Matrix, urban park, World Heritage site, marine park, factor analysis.

*Prof Melville Saayman is professor at TREદS: Tourism Research in Economic Environs and Society, North-West University, Potchefstroom, South Africa.

\#Prof Andrea Saayman is a professor in the School of Economics, North-West University, Potchefstroom, South Africa.

+Prof Riaan Rossouw is associate professor in the School of Economics, North-West University, Potchefstroom, South Africa. 


\section{INTRODUCTION}

The role and contribution of local communities in managing national parks have changed significantly over the past few years. This has been brought about by a paradigm shift at the national conservation agency, South African National Parks (hereafter referred to as SANParks) from traditionally being a pure conservation agency to becoming a conservation agency striving to benefit and empower local communities (Venter, Naiman, Biggs \& Pienaar, 2008). In light of this, SANParks has three primary objectives: i) to conserve the biodiversity of the country; ii) to maintain a relationship of community upliftment and capacity building among people living in the areas neighbouring the parks; and iii) to provide a tourism and recreational outlet that allows people to enjoy the wonders of the parks (Streuders, 2008). Objectives 2 and 3 provide the rationale for research into the socio-economic impact of national parks in South Africa.

There is a growing body of literature on the effects and importance of protected areas on adjacent communities (see, for example, Simelane, Kerley \& Knight, 2006; Simpson, 2008; Streuders, 2008). Adams and Hutton (2007) state that this implies 'the compatibility of conservation and poverty alleviation', and that setting aside land for conservation purposes inevitably has social and economic impacts. In addition to the issue of displacement, the most noteworthy social effects of protected areas on the adjacent communities include the restriction of communities to inhabit and live from the land, the costs due to damages to local crops and human deaths caused by wild animals, and a change in the way local communities view themselves and their environment (see e.g. West, Igoe \& Brockington, 2006; Adams \& Hutton, 2007; Saayman, Rossouw \& Saayman, 2012). In the case of an urban park, the relationship between conservation and the local community may be even more tense and should be managed in a more effective way (Oberholzer, Saayman, Saayman \& Slabbert, 2009). Phillips (1998) stresses the importance and usefulness of socio-economic impact studies in providing information to governments and organisations, in this case SANParks, on projects that seek funding, subsidies, tax incentives, land use, or other forms of policy assistance.

The largest urban park in South Africa is the Table Mountain National Park (TMNP), which is situated at the south-western tip of Africa and stretches from Signal Hill in Cape Town, south to South Point. This park is part of the existing 21 South African National Parks and was established in 1998. The current size of the park is 25000 hectares, and its jurisdiction stretches over $1000 \mathrm{~km}^{2}$ of seas and coastlines around the peninsula (SANParks, 2012). This park is also known for the two world-renowned landmarks, Table Mountain and the Cape of Good Hope. The park borders several communities - from extremely rich, to extremely poor. The park also attracts the greatest number of visitors of all the national parks in South Africa and therefore has a clear economic and social impact and responsibility. This article aims to shed some light on the relationship between conservation and communities in a metropolitan setting by assessing the socio-economic impact of the Table Mountain National Park on the various communities adjacent to the park. The only other socio-economic study conducted at an urban national park, which is also a marine park, was done by Oberholzer et al. (2009) focusing on Wilderness National Park in South Africa, and this study also recommended that more research on this topic should be conducted. 


\section{LITERATURE REVIEW}

A socio-economic study assesses the influence of a certain tourism development or activity on aspects such as income generated, employment created, perceived benefits to the community, and contribution to the local and regional economy (Van der Merwe, 2008). In 2010, Saayman and Saayman criticised the misuse of the concept 'socio-economic impact' in many studies when researchers are, in fact, determining only the economic impacts. They indicated that a socio-economic impact study should go beyond assessing the income generated by the park or tourism activity and should also involve the contribution that the park makes to the quality of life of people in neighbouring communities.

In this regard, several factors can be identified that influence the magnitude of the impact of national parks on local economies and communities. These include: the levels of unemployment and development of the adjacent communities; the level of development of the tourism infrastructure (accommodation, road infrastructure, number and variety of species and activities); the location of the park; the level of business and industrial development, as well as the size of the neighbouring town(s); and the level of community participation in the park and the way that communities perceive the park (Saayman \& Saayman, 2010). Some of these aspects are difficult to quantify in monetary terms, whilst others are not quantifiable at all. Despite the criteria, several recent studies still use the concept inappropriately and the focus remains on economic aspects (see for example Ezebilo \& Mattsson, 2010; Dicken \& Hosking, 2009).

Based on the above, one could also refer to the quantifiable aspects as hard-core factors that deal primarily with economic aspects (see FIGURE 1), while most of the social indicators or aspects are difficult to quantify in monetary terms. They could therefore be regarded as softcore aspects in socio-economic studies. However, both are important from a socio-economic point of view.

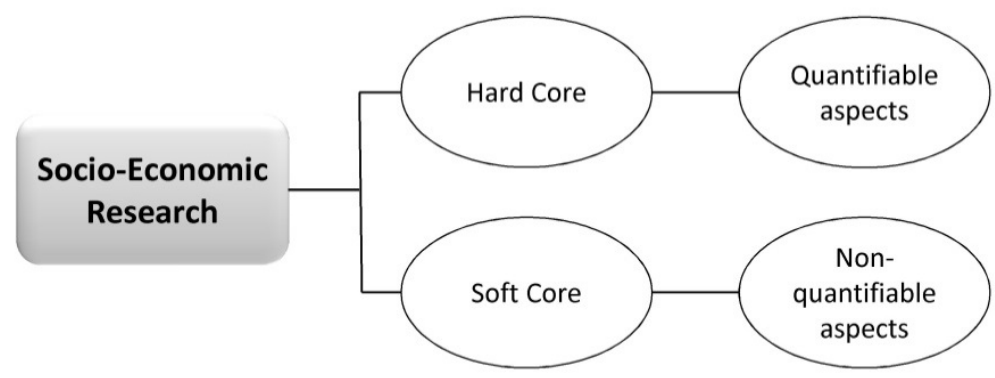

\section{FIGURE 1: Aspects pertaining to socio-economic research}

\section{Source: Authors'compilation}

A review of the literature reveals that several studies have been conducted on social and community (soft) issues pertaining to conservation or protected areas. These include research by Scheyvens (1999), Simelane et al. (2006), Cernea and Schmidt-Soltau (2006), West et al. (2006) and Goodwin (2002). In terms of the economic impact of conservation areas, research includes that by Standish, Boting, Van Zyl, Leiman and Trupie (2004), Engelbrecht and van der Walt (1993), Saayman and Saayman (2006a), Mahoney and van Zyl (2002), Vaughan, Farr and Slee (2000) and Samuelsson and Stage (2007), Spenceley and Goodwin (2008), Huhtala, Kajala and Vatanen, (2010), Ezebilo and Mattsson (2010), Dicken and Hosking (2009), Sandbrook 
(2010). Research conducted on the socio-economic impact of conservation areas includes research by Taylor, Gough, Warren and McClintock (1999), Akama and Kieti (2007), Saayman and Saayman (2006b, 2010), Mbaiwa (2003, 2004, 2005), Motlanke (2005), Oberholzer et al. (2009), and Saayman, Saayman and Ferreira, (2009).

Results from these studies revealed the following: first, that parks in general have positive economic spin-offs and benefits to communities. Second, in most cases, communities are positive about national parks. Third, communities indicated that national parks contributed to their quality of life. However, the more developed a national park in terms of infrastructure (road infrastructure, shops, number of accommodation units), the number of activities (e.g. game drives, hiking trails, etc.) and the number of species, the greater the benefits. National parks located in more touristic areas have higher leakages than those in areas where other industries are also available, which increases the economic benefits derived by local communities. Lastly, underprivileged communities expect national parks to do more in terms of job creation and economic benefits than do privileged (rich) communities.

\section{METHODOLOGY}

To address both soft- and hard-core issues pertaining to socio-economics, the methodology used included two surveys - a community and visitor survey. The questionnaires and surveys are described before the data analysis techniques are explained.

\subsection{The questionnaire}

A questionnaire was developed for visitors to the park, based on the questionnaires used by Oberholzer et al. (2009) and Saayman et al. (2009). The visitor questionnaire collected demographic data, expenditure patterns, reasons for people's visits to the park, consumer behaviour as well as the way that the respondents perceived the level of service in the park. A structured questionnaire for the visitor survey was divided into four sections. Section A determined the socio-demographic information of the respondents with regard to their gender, age, home language, marital status, and province of residence. Section B determined the spending behaviour. Section C was used to determine the tourists' perception of the facilities in the park and Section $D$ determined the reasons and motives for tourists visiting the park

A separate questionnaire for people living in the communities surrounding the park was developed to address the social impact of the park, and it was based on research by Mbaiwa $(2003,2004,2005)$ and Oberholzer et al. (2009). The social impact questionnaire not only collected demographic data, it also determined the perceptions of communities surrounding the TMNP with 36 Likert-scale statements, and locals' visits to the park. This social questionnaire consisted of three sections. Section A looked at socio-demographic aspects. Section B determined the use and reason for visiting or not visiting the park and Section $C$ determined the park's contribution to their quality of life. 


\subsection{Sampling method and survey}

\subsubsection{Survey A: Visitors}

All tourists entering the park at the Table Mountain Cable Car, Boulders and the Good Hope during the period of the survey, and who were willing to complete the questionnaire, formed part of the survey. The questions consisted of three sections: Section A determined the sociodemographic profile, Section B focused on travel motives and Section $C$ on spending behaviour. The questionnaires were distributed by well-trained fieldworkers during the period from 27 March to 1 April 2010. During March 2009 and March 2010, according to SANParks (2010) a total of 2372271 tourists visited the park, although 673356 tourists entered at the three points that were used for the purpose of this survey. The reason for using these three points of entry was that these are where the main attractions are located, and it is difficult to have fieldworkers at all entry points, since there are open access areas. A total of 505 useable questionnaires were returned during the survey. According to Israel (2009:6) in a population of $>100000(\mathrm{~N}), 398$ respondents $(n)$ are seen as representative and result in a $95 \%$ level of confidence with a $\pm 5 \%$ sampling error. Therefore, 505 completed questionnaires are sufficient for the purpose of this research.

\subsubsection{Survey B: Social impact}

In total, 580 questionnaires were randomly distributed by fieldworkers in various suburbs that are adjacent to the park. The questionnaires were distributed as follows: Claremont (80), Hout Bay (80), Fish Hoek (80), Simon's Town (80), Constantia (60), Tokai (60), Muizenberg (70) and Kalk Bay (70). The questionnaires were distributed between 27 March and 1 April 2010. Approximately 55000 residents live in these suburbs and only these residents were allowed to complete the questionnaires (STATSSA, 2001). Based on Israel (2009:6), who states that for a population of $<100000(N), 398$ respondents $(n)$ are seen as representative and result in a $95 \%$ level of confidence with $a \pm 5 \%$ sampling error, 551 completed questionnaires are adequate. The questionnaire used comprised two sections: socio-demographic information of residents and the way that the park impacts on their quality of life. Thirty-six constructs evaluate a variety of social aspects such as crime and how residents benefit from the park. These constructs were evaluated on a 5 -point Likert scale where 1 indicated that residents totally disagree and 5 indicated total agreement.

\subsection{Data analysis}

The data analysis was done in two processes: one modelled the economic impact by means of multipliers calculated from a Social Accountings Matrix (SAM) for the Western Cape and the second analysed the social impact by means of a factor analysis. In terms of the economic analysis, the visitors' survey data was captured in Excel and split between the various entrances to the park and according to the origin of the visitors, as proposed by Stynes and White (2006). Three groups of visitors were identified as (i) visitors from the Western Cape in which the park is situated, (ii) visitors from the rest of South Africa, and (iii) international visitors. By splitting the respondents into various groups, a more accurate value of spending can be determined (Saayman, Saayman \& du Plessis, 2005).

It is often argued that spending by locals (in this instance, visitors from Western Cape) should be excluded, since it represents merely a shift in expenditure patterns and not new money that 
flows into the region. However, Crompton (2006) indicates that there are two circumstances when local spending can be included: (i) when the existence of the park caused the residents to stay at home rather than take a trip elsewhere, referred to as the 'deflected impact', and (ii) when a study of the significance of the park is made, i.e. the size and nature of the influence of the park on local economic activity. Since the focus of this article is on the significance of the park to the local economy (i.e. option (ii) listed above), spending by visitors from the province of the Western Cape is included in the analysis. The contribution is, however, always listed separately in the analysis.

The responses from the questionnaire are used to gather expenditure information from visitors groups. Since spending is reflected per group, it is necessary to determine the size of the visitor group before spending per person can be ascertained. The survey revealed that Western Cape visitors travel in visitor groups of 4.55, other South African visitors in visitor groups of 3.67 and international visitors in visitor groups of 3.61. The magnitude of spending for each category was therefore divided by the number of visitors in the group, to derive the value of spending per visitor.

The SANParks database indicated that 673356 visitors visited the TMNP at the three points of the survey for the year ending March 2010. The number of visitors from each origin was obtained based on the percentage distribution of the survey. Accordingly, 110272 visitors were from the Western Cape, 145517 from the rest of South Africa, and 408568 were international visitors. By multiplying the number of visitors with the spending per visitor, total spending of visitors from different origins due to the park can be derived. The breakdown of visitor spending per origin is provided in TABLE 1 .

TABLE 1: Total spending of visitors according to origin (in ZAR millions, 2006 prices)

\begin{tabular}{lcccc}
\hline \multicolumn{1}{c}{ Spending item } & Western Cape & Rest of RSA & International & $\begin{array}{c}\text { Total visitors' } \\
\text { spending }\end{array}$ \\
\hline Entrance fee & 8.635 & 23.827 & 26.318 & 58.780 \\
Restaurants & 3.584 & 8.563 & 11.564 & 23.711 \\
Food & 1.040 & 4.653 & 7.321 & 13.014 \\
Beverages & 1.387 & 4.295 & 3.812 & 9.495 \\
Transport to park & 1.066 & 2.953 & 11.330 & 15.349 \\
Activities & 0.000 & 2.339 & 11.008 & 13.348 \\
Souvenirs & 0.379 & 2.629 & 1.820 & 4.829 \\
Total & 16.092 & 49.260 & 73.174 & 138.526 \\
\hline
\end{tabular}

Source: Authors' compilation based on survey results

TABLE I presents a breakdown of the activity sectors where expenditure was incurred. The total direct spending that takes place in the Western Cape economy amounts to ZAR138.5 million, of which ZAR16.1 million is contributed by local visitors and ZAR49.3 and ZAR73.2 million by visitors from the rest of South Africa and abroad respectively. 
The total spending by visitors from different origins was allocated to the categories of the Western Cape SAM. Since a SAM multiplier approach is followed, distinct multipliers for each expenditure-related economic activity are applied. The subsequent change in commodity demand is therefore translated into a change in economic activity by using the SAM multipliers the so-called 'corrected' direct impact of the event. The multipliers then convert the spending into the associated increase in production, income and employment opportunities due to the circulation of the additional spending through the local economy.

\subsection{Factor analysis: social impact}

To determine the social impact, a factor analysis was applied. An Oblimin rotation with Kaiser Normalisation was performed on the 36 social statements to explain the variance-covariance structure of a set of variables through linear combinations of these variables. The Kaiser-MeyerOlkin measure of sampling adequacy was also used to determine whether the covariance matrix was suitable for factor analysis. Kaiser's criteria for the extraction of all factors with eigenvalues larger than unity were used because they were considered to explain a significant amount of variation in the data. In addition, all items with a factor loading above 0.3 were considered as contributing to a factor, and all with loadings lower than 0.3 as not correlating significantly with this factor (Steyn, 2000). In addition, any item that cross-loaded on two factors with factor loadings greater than 0.3 was categorised in the factor where interpretability was best. A reliability coefficient (Cronbach's alpha) was furthermore computed to estimate the internal consistency of each factor. The factor analysis explained $65.4 \%$ of the variance.

\section{RESULTS}

\subsection{Multiplier analysis results}

The results of the analysis are discussed by assessing the influence of spending by visitors to the TMNP on production in the Western Cape, on income of households in the province as well as on job creation in the province. The initial stimulus of additional spending in the economy creates an inflow into the economy that stimulates further economic activity. Production can be seen as the total turnover that is generated by each sector in the economy, and the increase in production due to the spending stimulus is summarised in TABLES 2 and 3.

TABLE 2: Direct, indirect and induced impact of spending on production (in ZAR millions, 2006 prices)

\begin{tabular}{|c|c|c|c|c|c|c|}
\hline \multirow[b]{2}{*}{ Sector } & \multicolumn{2}{|c|}{ Western Cape } & \multicolumn{2}{|c|}{ Rest of RSA } & \multicolumn{2}{|c|}{ International } \\
\hline & $\begin{array}{l}\text { Direct } \\
\text { and } \\
\text { Indirect }\end{array}$ & Induced & $\begin{array}{l}\text { Direct } \\
\text { and } \\
\text { Indirect }\end{array}$ & Induced & $\begin{array}{l}\text { Direct } \\
\text { and } \\
\text { Indirect }\end{array}$ & Induced \\
\hline Agriculture & 0.037 & 0.009 & 0.098 & 0.022 & 0.139 & 0.031 \\
\hline Mining & 0.005 & 0.002 & 0.016 & 0.005 & 0.028 & 0.009 \\
\hline Manufacturing & 1.507 & 0.329 & 4.383 & 0.968 & 6.699 & 1.467 \\
\hline Electricity \& water & 0.077 & 0.020 & 0.217 & 0.055 & 0.361 & 0.092 \\
\hline
\end{tabular}




\begin{tabular}{lcccccc|}
\hline & \multicolumn{2}{c}{ Western Cape } & \multicolumn{2}{c}{ Rest of RSA } & \multicolumn{3}{c}{ International } \\
\multicolumn{1}{c}{ Sector } & $\begin{array}{c}\text { Direct } \\
\text { and } \\
\text { Indirect }\end{array}$ & Induced & $\begin{array}{c}\text { Direct } \\
\text { and } \\
\text { Indirect }\end{array}$ & Induced & $\begin{array}{c}\text { Direct } \\
\text { and } \\
\text { Indirect }\end{array}$ & Induced \\
\hline Construction & 0.058 & 0.010 & 0.178 & 0.032 & 0.258 & 0.046 \\
Trade \& accommodation & 8.385 & 2.262 & 25.899 & 7.061 & 34.337 & 9.346 \\
Transport \& communication & 2.947 & 0.688 & 8.941 & 2.090 & 18.748 & 4.353 \\
Financial \& business services & 12.302 & 3.348 & 37.502 & 10.200 & 54.499 & 14.821 \\
Community services & 0.273 & 0.093 & 0.828 & 0.283 & 1.311 & 0.447 \\
\hline Total (in ZAR million) & 25.592 & 6.761 & 78.061 & 20.717 & 116.380 & 30.611 \\
\hline
\end{tabular}

Source: Authors' calculations based on multiplier analysis

Initial expenditures (for example, by visitors) are generally called the direct costs of an activity, and their effects on the economy are direct effects.

Purchases by suppliers (for example, vendors, hotel and restaurant owners, charter operators, etc.) of the final goods and services of materials and supplies to sustain the original purchases are called indirect effects.

Induced effects occur when workers in the sectors stimulated by direct and indirect expenditures spend their additional income on consumer goods and services.

TABLE 2 presents a breakdown of the direct, indirect and induced impacts on production of visitor spending due to the activity at the TMNP, according to origin. For ease of interpretation, the results are summarised in sectors of the economy, using the basic sector aggregation as classified by the South African Reserve Bank and Statistics South Africa. It is evident that the direct and indirect impact of spending by visitors from abroad exceeds that of other visitor groups. This is to be expected, since they form the majority of the park visitors.

TABLE 2 also shows that the tourism-related sectors, i.e. financial and business services, trade and accommodation, and transport and communication (refer to FIGURE 1), are the sectors in the Western Cape that benefit greatly from tourism activities due to the TMNP. Through backward linkages, the indirect and induced effects on manufacturing as well as community and personal services are also noteworthy.

TABLE 3 summarises the total impact of visitors to the TMNP.

It shows that the value of the park to production in the province exceeds ZAR278 million. If local spending is excluded (i.e. visitors from the Western Cape), the value of the TMNP to the local economy is ZAR245.77 million. Visitors from the rest of South Africa as well as international visitors are the main contributors to the increase in production. Local spending, on the other hand, is the lowest contributor to the increase in production, although it has a substantial effect on the building and financial and business services sectors of the provincial economy.

In total, the sectors that benefit the most in terms of output due to visitors to the TMNP are, in order of importance, financial and business services (47.7\%), trade and accommodation $(31.4 \%)$, transport and communication (13.67\%), manufacturing (5.5\%), and community and personal services (1.2\%). 


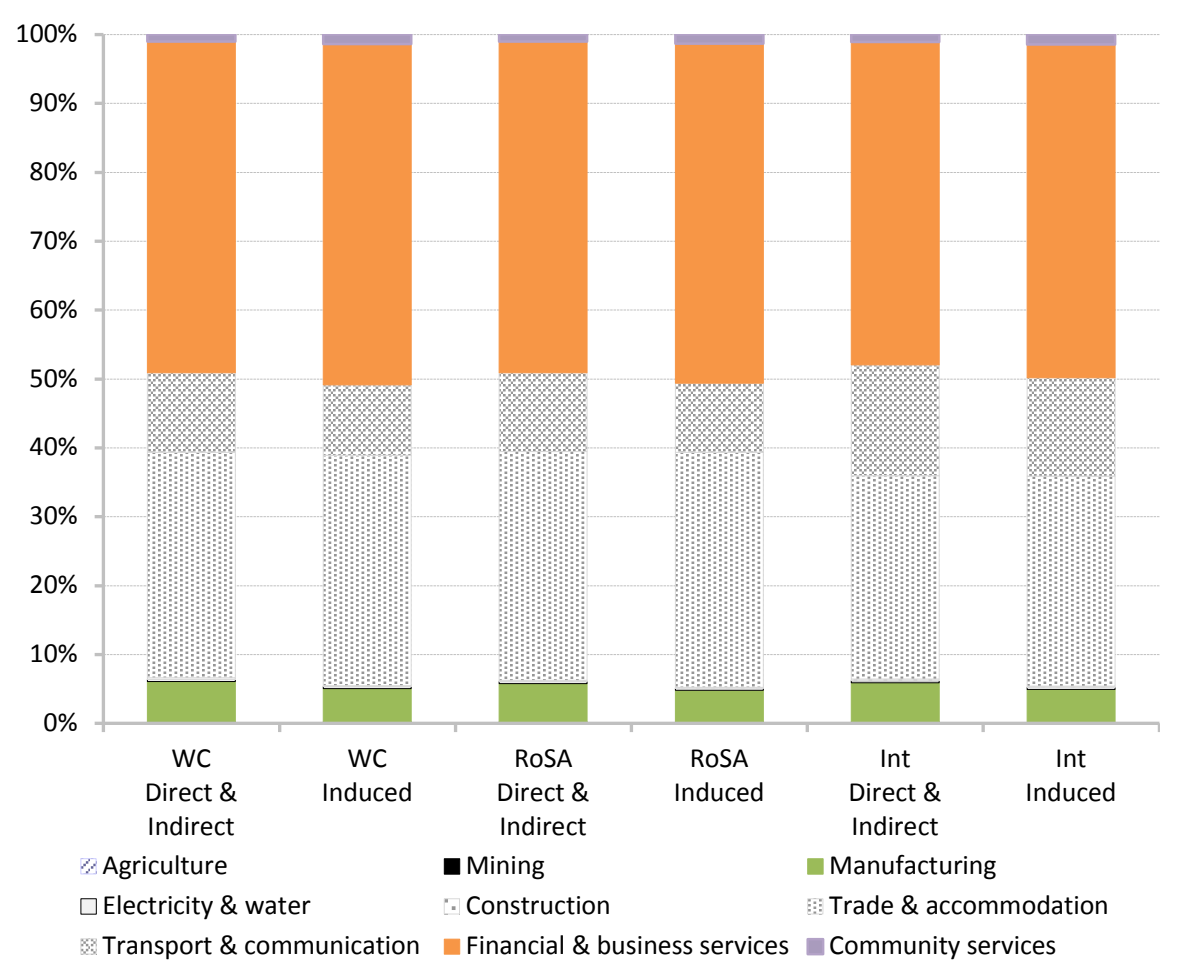

FIGURE 2: Visitors' expenditure in the region per activity sector

Source: Authors'analysis

TABLE 3: Total impact of the TMNP on production (in ZAR millions, 2006 prices)

\begin{tabular}{lccccc}
\hline \multicolumn{1}{c}{ Sector } & $\begin{array}{c}\text { Western } \\
\text { Cape }\end{array}$ & Rest of RSA & $\begin{array}{c}\text { Interna- } \\
\text { tional }\end{array}$ & Total & Percentage \\
\hline Agriculture & 0.046 & 0.120 & 0.171 & 0.336 & $0.12 \%$ \\
Mining & 0.007 & 0.021 & 0.037 & 0.065 & $0.02 \%$ \\
Manufacturing & 1.836 & 5.350 & 8.166 & 15.352 & $5.52 \%$ \\
Electricity \& water & 0.097 & 0.273 & 0.453 & 0.822 & $0.30 \%$ \\
Construction & 0.069 & 0.209 & 0.304 & 0.582 & $0.21 \%$ \\
Trade \& accommodation & 10.648 & 32.960 & 43.683 & 87.290 & $31.39 \%$ \\
Transport \& communication & 3.636 & 11.031 & 23.101 & 37.768 & $13.58 \%$ \\
Financial \& business services & 15.649 & 47.702 & 69.320 & 132.671 & $47.70 \%$ \\
Community services & 0.366 & 1.111 & 1.758 & 3.235 & $1.16 \%$ \\
\hline Total & 32.353 & 98.778 & 146.992 & 278.123 & $100.00 \%$ \\
\hline
\end{tabular}

Source: Authors' calculations based on multiplier analysis 
An increase in spending leads not only to an increase in production, but also to an increase in employee remuneration. Therefore, the spending stimulus due to tourism activity in the park also has an effect on household income in the province. The resulting income multipliers derived from the Western Cape SAM are used to quantify the effect of the TMNP on household income. Since the income (or gross value added) effect is seen as more realistic in estimating the increase in economic activity due to the park (see Blake 2005), is it also reported according to each segment. It is estimated that the TMNP contributed almost ZAR133.3 million in income to households in the Western Cape (see TABLE 4).

TABLE 4: Total impact of the TMNP on income (in ZAR millions, 2006 prices)

\begin{tabular}{lccccc}
\hline \multicolumn{1}{c}{ Sector } & $\begin{array}{c}\text { Western } \\
\text { Cape }\end{array}$ & $\begin{array}{c}\text { Rest of } \\
\text { RSA }\end{array}$ & $\begin{array}{c}\text { Interna- } \\
\text { tional }\end{array}$ & Total & $\begin{array}{c}\text { Percentag } \\
e\end{array}$ \\
\hline Agriculture & 0.069 & 0.055 & 0.028 & 0.152 & $0.11 \%$ \\
Mining & 0.027 & 0.006 & 0.007 & 0.040 & $0.03 \%$ \\
Manufacturing & 2.480 & 2.450 & 1.241 & 6.171 & $4.63 \%$ \\
Electricity \& water & 0.197 & 0.099 & 0.075 & 0.371 & $0.28 \%$ \\
Construction & 0.051 & 0.110 & 0.040 & 0.201 & $0.15 \%$ \\
Trade \& accommodation & 20.702 & 13.144 & 8.417 & 42.263 & $31.70 \%$ \\
Transport \& communication & 7.438 & 6.423 & 3.221 & 17.082 & $12.81 \%$ \\
Financial \& business services & 32.125 & 20.512 & 12.843 & 65.480 & $49.12 \%$ \\
Community services & 0.693 & 0.482 & 0.370 & 1.546 & $1.16 \%$ \\
\hline Total & 63.782 & 43.282 & 26.243 & 133.307 & $100.00 \%$ \\
\hline
\end{tabular}

Source: Authors' calculations based on multiplier analysis

It is evident that the impact via income multipliers is considerably less than that proposed by the production multipliers (ZAR278 million versus ZAR133 million), which confirms the concerns raised in the literature that focusing only on the production effect of a spending stimulus may paint an unrealistic positive picture of the economic impact of tourism activity in the park.

Of special importance is the effect of the park on the income of low-income households, since it provides an indication of the effect on poverty alleviation in the province. Income categories $\mathrm{Pl}$ to P5 are considered to be low-income, which translates into income less than ZAR24 000 per year (i.e. less than US\$3 000 per year). TABLE 5 summarises the impact of the TMNP on income.

From the tables it is clear that the TMNP generated income of almost ZAR126.9 million for households in the Western Cape. Low-income households receive about $4 \%$ of this income. The labourers in the trade and accommodation sector experience the greatest increase in income, followed by those in the manufacturing and in other tourism-related services sectors i.e., transport and communication, and business and financial services. If one were to exclude visitors from Western Cape, the total impact on income will still be in excess of ZAR117 million. 
TABLE 5: Total impact of the TMNP on household income (in ZAR millions, 2006 prices)

\begin{tabular}{|c|c|c|c|c|c|}
\hline \multirow[b]{2}{*}{ Sector } & \multicolumn{5}{|c|}{ Indirect and induced impacts } \\
\hline & Total impact & $\begin{array}{c}\text { Low- } \\
\text { income } \\
\text { households }\end{array}$ & $\begin{array}{c}\text { Other } \\
\text { households }\end{array}$ & $\begin{array}{c}\text { Total } \\
\text { households }\end{array}$ & Percentage \\
\hline Agriculture & 0.336 & 0.01 & 0.11 & 0.12 & $0.1 \%$ \\
\hline Mining & 0.065 & 0.00 & 0.02 & 0.03 & $0.0 \%$ \\
\hline Manufacturing & 15.352 & 0.31 & 5.44 & 5.74 & $4.8 \%$ \\
\hline Electricity \& water & 0.822 & 0.02 & 0.28 & 0.30 & $0.2 \%$ \\
\hline Construction & 0.582 & 0.01 & 0.20 & 0.21 & $0.2 \%$ \\
\hline Trade \& accommodation & 87.290 & 1.82 & 35.21 & 37.04 & $30.8 \%$ \\
\hline $\begin{array}{l}\text { Transport \& } \\
\text { communication }\end{array}$ & 37.768 & 0.62 & 15.32 & 15.94 & $13.2 \%$ \\
\hline $\begin{array}{l}\text { Financial \& business } \\
\text { services }\end{array}$ & 132.671 & 1.97 & 57.30 & 59.27 & $49.2 \%$ \\
\hline Community services & 3.235 & 0.11 & 1.68 & 1.78 & $1.5 \%$ \\
\hline Total & 278.123 & 4.86 & 115.57 & 120.43 & $100.0 \%$ \\
\hline
\end{tabular}

Source: Authors' calculations based on multiplier analysis

Finally, the spending stimulus also leads to job creation. Since labour is a key input in the production process, an increase in production is associated with an increase in employment. The number of jobs created per activity sector is based on the figures obtained in the Western Cape SAM, as well as data on the labour force per province relative to business volume and jobs per activity sector in South Africa for 2006. TABLE 7 summarises the results of the impact of visitors to the TMNP on the regional employment level in the province.

From TABLE 6, it is evident that 871 job opportunities may depend on the TMNP, in addition to the job opportunities of people directly involved or employed at the park. In the absence of the TMNP, 871 job opportunities might be lost, most of these in the trade and accommodation sector. Other sectors also affected include financial and business services, manufacturing and transport and communication, with the business and community service sectors also benefiting from the park in terms of employment opportunities.

\subsection{Results of the social impact}

Respondents were first asked to indicate to what extent the TMNP affected their personal quality of life. $67 \%$ felt that the park had a positive impact on their lives, while $31 \%$ felt that it had no effect and only $2 \%$ found it to be negative. From this, one could confidently say that the park has a positive impact on the perceived quality of life of local communities. 
TABLE 6: Total impact of spending on employment

\begin{tabular}{lcccc}
\hline \multicolumn{1}{c}{ Sector } & Total impact & $\begin{array}{c}\text { Labour } \\
\text { multiplier }\end{array}$ & $\begin{array}{c}\text { Number of } \\
\text { jobs }\end{array}$ & $\begin{array}{c}\text { Percentage } \\
\text { (total) }\end{array}$ \\
\hline Agriculture & 0.336 & 20.93 & 7 & $0.8 \%$ \\
Mining & 0.065 & 4.82 & 0 & $0.0 \%$ \\
Manufacturing & 15.352 & 3.63 & 55 & $6.3 \%$ \\
Electricity \& water & 0.822 & 4.91 & 2 & $0.2 \%$ \\
Construction & 0.582 & 11.26 & 3 & $0.4 \%$ \\
Trade \& accommodation & 87.290 & 11.12 & 491 & $56.4 \%$ \\
Transport \& communication & 37.768 & 1.67 & 36 & $4.2 \%$ \\
Financial \& business services & 132.671 & 5.89 & 260 & $29.8 \%$ \\
Community services & 3.235 & 15.54 & 17 & $1.9 \%$ \\
\hline Total & $278.123 *$ & & 871 & $100 \%$ \\
\hline
\end{tabular}

Source: Authors' calculations based on multiplier analysis

Secondly, the 36 statements pertaining to the social impact of the TMNP were subjected to a factor analysis, as described in the method of research. The results of the factor analysis are indicated in TABLE 7 .

TABLE 7: Results of the factor analysis on social statements

\begin{tabular}{|c|c|c|c|c|}
\hline CSFs and items & $\begin{array}{l}\text { Factor } \\
\text { loading }\end{array}$ & $\begin{array}{l}\text { Mean } \\
\text { value }\end{array}$ & $\begin{array}{l}\text { Reliability } \\
\text { coefficient }\end{array}$ & $\begin{array}{l}\text { Average } \\
\text { inter-item } \\
\text { correlation }\end{array}$ \\
\hline Factor 1 :Social and Economic Opportunities & & 3.62 & 0.76 & 0.38 \\
\hline Opportunities to meet new people & 0.665 & & & \\
\hline $\begin{array}{l}\text { Opportunities for local businesses have } \\
\text { increased }\end{array}$ & 0.496 & & & \\
\hline $\begin{array}{l}\text { The number of tourists visiting the area has } \\
\text { increased }\end{array}$ & 0.418 & & & \\
\hline $\begin{array}{l}\text { Facilities available to local residents have } \\
\text { improved }\end{array}$ & 0.421 & & & \\
\hline $\begin{array}{l}\text { Interaction between locals and tourists have } \\
\text { improved }\end{array}$ & 0.532 & & & \\
\hline Factor 2:Relocaton and removals & & 3.07 & 0.72 & 0.56 \\
\hline $\begin{array}{l}\text { The park has affected the community } \\
\text { negatively by relocating people for } \\
\text { conservation purposes }\end{array}$ & 0.756 & & & \\
\hline The park is insensitive towards the community & 0.799 & & & \\
\hline Journal of Economic and Financial S & $/ 1 \varepsilon$ & & $9-458$ & \\
\hline
\end{tabular}




\begin{tabular}{|c|c|c|c|c|}
\hline CSFs and items & $\begin{array}{l}\text { Factor } \\
\text { loading }\end{array}$ & $\begin{array}{l}\text { Mean } \\
\text { value }\end{array}$ & $\begin{array}{l}\text { Reliability } \\
\text { coefficient }\end{array}$ & $\begin{array}{c}\text { Average } \\
\text { inter-item } \\
\text { correlation }\end{array}$ \\
\hline \multicolumn{5}{|l|}{$\begin{array}{l}\text { concerning the removal of alien animal } \\
\text { species }\end{array}$} \\
\hline Factor 3: Improvements & & 3.35 & 0.77 & 0.45 \\
\hline $\begin{array}{l}\text { Employment opportunities in the area have } \\
\text { increased }\end{array}$ & 0.675 & & & \\
\hline $\begin{array}{l}\text { The range of things to do in the area has } \\
\text { increased }\end{array}$ & 0.603 & & & \\
\hline $\begin{array}{l}\text { Facilities available to local residents have } \\
\text { improved }\end{array}$ & 0.500 & & & \\
\hline Social and moral values have improved & 0.584 & & & \\
\hline Factor 4: Neglect & & 2.59 & 0.68 & 0.52 \\
\hline $\begin{array}{l}\text { Residents do not get the opportunity to } \\
\text { benefit economically from projects in the park }\end{array}$ & 0.755 & & & \\
\hline $\begin{array}{l}\text { Residents do not get sufficient information } \\
\text { regarding activities in the park }\end{array}$ & 0.793 & & & \\
\hline Factor 5: Improved Image & & 3.80 & 0.76 & 0.44 \\
\hline The appearance of the area has improved & 0.764 & & & \\
\hline Natural resources of the area are conserved & 0.830 & & & \\
\hline $\begin{array}{l}\text { The pride that residents have in their } \\
\text { community has improved }\end{array}$ & 0.471 & & & \\
\hline The natural environment has been sustained & 0.519 & & & \\
\hline Factor 6: Improved Business & & 3.90 & 0.81 & 0.51 \\
\hline $\begin{array}{l}\text { There are opportunities for people to have fun } \\
\text { with family and friends }\end{array}$ & 0.631 & & & \\
\hline $\begin{array}{l}\text { The money that tourists spend in the TMNP } \\
\text { helps to stimulate the economy }\end{array}$ & 0.787 & & & \\
\hline $\begin{array}{l}\text { Tourism and business development in the area } \\
\text { are promoted }\end{array}$ & 0.420 & & & \\
\hline $\begin{array}{l}\text { The community has the opportunity to visit a } \\
\text { national park }\end{array}$ & 0.446 & & & \\
\hline Factor 7: Negative Impacts & & 3.38 & 0.20 & 0.08 \\
\hline $\begin{array}{l}\text { The number of people in the area has } \\
\text { increased }\end{array}$ & 0.665 & & & \\
\hline Property values in the area have increased & 0.495 & & & \\
\hline Crime levels have increased & 0.770 & & & \\
\hline
\end{tabular}




\begin{tabular}{|c|c|c|c|c|}
\hline CSFs and items & $\begin{array}{l}\text { Factor } \\
\text { loading }\end{array}$ & $\begin{array}{l}\text { Mean } \\
\text { value }\end{array}$ & $\begin{array}{l}\text { Reliability } \\
\text { coefficient }\end{array}$ & $\begin{array}{c}\text { Average } \\
\text { inter-item } \\
\text { correlation }\end{array}$ \\
\hline $\begin{array}{l}\text { Prices of some goods and services have } \\
\text { increased }\end{array}$ & 0.652 & & & \\
\hline Factor 8: Park Knowledge & & 3.42 & 0.49 & 0.16 \\
\hline $\begin{array}{l}\text { Ordinary residents get no say in the planning } \\
\text { and management of the TMNP }\end{array}$ & 0.400 & & & \\
\hline $\begin{array}{l}\text { The park has an important role to play in } \\
\text { removing alien species }\end{array}$ & 0.534 & & & \\
\hline $\begin{array}{l}\text { The TMNP improves my knowledge with regard } \\
\text { to the environment, plants and animals }\end{array}$ & 0.509 & & & \\
\hline $\begin{array}{l}\text { The TMNP is accessible for us as members of } \\
\text { the community }\end{array}$ & 0.656 & & & \\
\hline $\begin{array}{l}\text { The TMNP has increased my interest in } \\
\text { activities such as hiking, birding and so on }\end{array}$ & 0.771 & & & \\
\hline Factor 9: Lack of control & & 2.94 & 0.12 & 0.01 \\
\hline
\end{tabular}

There is not enough control over who enters the park

Insufficient control causes veld fires and other problems that endanger the residents

Many people are brought into the community

\subsection{7}

Factor 10: Management of wildlife 2.88 0.57

Due to the park, wild animals cause the community problems

The park needs to be fenced properly

0.878

$\begin{array}{lll}\text { Factor 11: Use of natural resources } & \text { N/A N/A N }\end{array}$

The park gives opportunities to the community to use its natural resources e.g. fishing

\subsection{4}

TOTAL VARIANCE EXPLAINED

$65.44 \%$

Source: Authors' calculations based on multiplier analysis

Based on the results of the factor analysis, 11 factors were extracted (see TABLE 7). The three factors with the highest mean values are improved business (3.90), improved image (3.80) and social and economic opportunities (3.62). These factors are all in the economic and marketing domain and are factors that are of direct benefit to the communities. Therefore respondents acknowledge the important economic and marketing role played by the park.

Two factors had an average below 0.4 and the reason for this lies in the diverse communities surrounding the park, since the rich community rated some aspects as being positive while the poor community rated the same aspect negative (for example, the park contributing to an 
increase in property prices). From the results it is also interesting to note the role played by the park in educating communities, since park knowledge (3.42) had the fourth-highest mean value.

Most of the negative statements fall under the social factors with low mean values, namely: neglect (2.59), lack of control (2.94) and management of wildlife (2.88), which implies that the respondents did not agree and this is an indication that park management is addressing them. $\mathrm{A}$ possible reason for this is that communities are of the opinion that these are things a conservation organisation does. The two factors that should be a cause for concern are relocation and removals (3.07) and negative impacts (3.38). Relocation and remova/s include items such as the park affecting the community negatively by re-locating people for conservation and the park being insensitive towards the removal of alien species. This result is a surprise, since earlier research did not find this an issue (see Oberholzer et al., 2009). In addition, negative impacts clearly showed that crime has increased, as did the number of people and prices of goods and services. These are important aspects and imply that park management should clearly communicate their policies and strategies in addressing such issues. Not one of the studies referred to in the literature review concerning the social impact has done a factor analysis on social constructs; therefore it is difficult to make comparisons. However, most of the previous studies also showed positive community perceptions regarding national parks. This is the first study that reveals that crime has increased and the fact that a large section of the park has open access might have something to do with that.

\section{FINDINGS AND IMPLICATIONS}

First and foremost, the results (see TABLE 7) show that the residents' perceptions are that the park has a positive economic and social impact. Results also confirm a greater economic than social impact, thereby contradicting results from a study conducted by Saayman et al. (2009) at Wilderness National Park, which is also an urban and marine national park in South Africa. However, one could confidently say the park is contributing to communities' quality of life, thereby supporting Taylor et al. (1999) and Oberholzer et al. (2009). The greatest challenge for park management is in terms of the social aspects. Problem areas indicated are relocation and removals and negative impacts, which include aspects such as increased prices and crime levels and the insensitivity of park management concerning removal of alien plant and animal species as well as relocation of people. The implication of these findings is that park management should communicate and interact with local communities on a regular basis concerning park policies, strategies and future plans. Park forums will help in establishing and growing relationships. In addition, more should be done in terms of dealing with crime, such as employing more field guides who are more visible as well as using cameras.

Based on the results from the economic analysis, the second finding reveals that the park generates approximately ZAR278 million for the region. This is significantly more than national parks, such as Addo Elephant (ZAR58,5 million); Karoo (ZAR10,5 million); Wilderness (ZAR15,1 million) and Tsitsikamma National Park (ZAR32,5 million) (see Saayman \& Saayman, 2010). This research confirms the important economic role that parks play (Mbaiwa, 2005; Taylor et al., 1999; Motlanke, 2005). This higher economic impact is mostly because of the large number of visitors, major drawcards or icons and lower leakages due to a variety of industries in and around Cape Town. However, it is also significantly less than the Kruger National Park, which generated in excess of ZAR2 billion (Saayman et al., 2012) - this despite the fact that the TMNP attracts in excess of 2 million visitors per year. The reasons for this are the short stay of visitors, 
limited accommodation (scale of operations) and a lack a variety of paid activities in the park. As in the case of the parks mentioned above, the sectors that benefit most from the tourist spend include financial and business services, trade and accommodation, and manufacturing.

The third finding shows that foreign visitors spend significantly more than the rest of South Africans (excluding visitors from the Western Cape), who, in turn, spend significantly more than visitors from the Western Cape. This fact contradicts research done in the other national parks in South Africa (see Saayman \& Saayman, 2010; Saayman et al., 2012), where South Africans are the big spenders. This is mostly because Cape Town is one of the key attractions of foreigners to South Africa and they tend to stay more centrally located in and around Cape Town to see and do as much as possible. In essence, one could argue that this park is not a destination, such as the Kruger National Park, but rather just an attraction. This implies that more accommodation is required as well as more activities, especially marine activities, which are greatly lacking. Activities such as boat rides, whale and dolphin watching and diving could be introduced. Marketing should focus on encouraging tourists to stay in the park for at least a night or two.

Fourthly, concerning job creation, results show that 871 people are dependent on the park and its activities, which is again significantly lower than that of the Kruger National Park (10 150 people); but more than Addo Elephant (434 people); Tsitsikamma (244 people); Wilderness (288 people) and Karoo National Park (244 people). More facilities and activities will have a direct impact on the number of people employed.

Fifthly, the results show that the park is achieving its objectives of conservation, economic contribution and social upliftment. However, it is clear that with such a large number of visitors the park could do much better, especially from an economic point of view. Aspects such as more types of accommodation as well as paid activities, including marine activities, should be introduced. This should have a significant impact on the socio-economic impact of the park. In addition, better communication and community relationships are required, especially concerning social and conservation progress, policies and strategies as indicated above.

The last finding is from a methodological point of view: this study shows that in the case of research conducted in a community with both extremely rich and poor residents, using the same questionnaire requires taking cognisance that some items for the poor community might be rated as negative, whereas the rich community rate them as positive. A good example is property value increases due to the park. This is seen as positive for the rich community but negative for the poor community, which still needs to acquire property.

\section{CONCLUSION}

The purpose of this research was to determine the socio-economic impact of South Africa's largest urban park, which is also a marine park. This was achieved by conducting two surveys (visitor and community), since it is difficult to get a holistic picture of the socio-economic value if one focuses just on one or the other. It was also the first time that a factor analysis on the social constructs was used in a socio-economic study conducted at a national park. Results clearly show that the park contributes to the quality of life of communities surrounding it. Results also reveal that the park has a significant economic impact although it could do much better. Clearly this research confirms that conservation can make a significant contribution to regional economies. It also showed that park management should carefully consider what a park offers to tourists and communities alike. Most of the residents are of the view that the biggest 
contribution of the park is on an economic and conservational level, although certain conservation activities are questionable. Social problems include an increase in crime, prices and number of people, all aspects that should be addressed by park management.

Another key contribution is that several factors are at play when it comes to socio-economic impact analyses, over and above the number of visitors: how long they stay, how much they spend, as well as leakages in the local economy. It is also important to acknowledge that economies of scale, in terms of accommodation and paid activities, play an important role in the magnitude of impact that the Park creates.

\section{Acknowledgements}

The authors would like to thank the following people and institutions who contributed towards the research: SANParks for funding received as well as supplying us with Parkspecific data; The respondents who completed questionnaires and the reviewers for their valuable contributions; This work is based on research supported in part by the National Research Foundation of South Africa (Grant specific unique reference number (UID) 85625). The Grantholder acknowledges that opinions, findings and conclusions or recommendations in any publication generated by the NRF supported research are that of the authors, and that the NRF accepts no liability whatsoever in this regard.

\section{LIST OF REFERENCES}

Adams, W.M. \& Hutton, J. (2007). Review - People, Parks and Poverty: Political Ecology and Biodiversity Conservation. Conservation and Society, 5(2), pp. 147-183.

Akama, J.S. \& Kieti, D. (2007). Tourism and socio-economic development in developing countries: A case study of Mombasa Resort in Kenya. Journal of Sustainable Tourism, 15(6), pp. 735-748.

Blake, A. (2005). The Economic Impact of the London 2012 Olympics, Research Report 2005/5. Christel de Haan Tourim and Travel Institute, Nottingham University.

Cernea, M.M. \& Schmidt-Soltau, K, (2006). Poverty Risks and National Parks: Policy issues in conservation and resettlement. World Development, 34(10), pp. 1808-1830.

Crompton, J.L. (2006). Economic impact studies; Instruments for political shenanigans? Journal of Travel Research, 45, pp.67-82.

Dicken, M.L. \& Hosking, S.G. (2010). Socio-economic aspects of the tiger shark diving industry within the Aliwal Shoal Marine Protected Area, South Africa. African Journal of Marine Science, 31(2), pp. 227-232.

Engelbrecht, W.G. \& Van der Walt, P.T. (1993). Notes on the economic use of the Kruger National Park. Koedoe, 36(2), pp. 113-120.

Ezebilo, દ.દ. \& Mattsson, L. (2010). Socio-economic benefits of protected areas as perceived by local people around Cross River National Park, Nigeria. Forest Policy and Economics, 12(1), pp. 189-193.

Goodwin, H. (2002). Local community involvement in tourism around national parks: Opportunities and constraints. Current /ssues in Tourism, 5(3/4), pp. 338-360. 
Huhtala, M., Kajala, L. \& Vatanen, દ. (2010). Local economic impacts of national park visitors' spending in Finland: The development process of an estimation method. [Online] Available: http://www.metla.fi/julkiasut/workingpaper/2010/mwpl49.htm (Accessed 25 April 2012)

Israel, G.D. (2009). University of Florida IFAS Extension. Determining the sample size. [Online] Available: http://edis.ifas.ufl.edu/pd00600pdf (Accessed 17 May 2011)

Mahoney, K. \& Van Zyl, J. (2002). The impacts of tourism investment on rural communities: three case studies in South Africa. Development Southern Africa, 19(1), pp. 83-103.

Mbaiwa, J.દ. (2003). The socio-economic and environmental impacts of tourism development on the Okavango Delta, north-western Botswana. Journal of Arid Environments, 54(2), pp. 447-464.

Mbaiwa, J.દ. (2004). The socio-economic impacts and challenges of a community-based safari hunting tourism in the Okavango Delta. Botswana. Journal of Tourism Studies, 15(2), pp. 37-50.

Mbaiwa, J.E. (2005). Enclave tourism and its socio-economic impacts in the Okavango Delta. Botswana. Tourism Management, 26, pp. 157-172.

Motlanke, S.G. (2005). The socio-economic impact of nature-based tourism: The case study of Bakgatla ba-ga Kgafela in the Pilanesberg National Park. [Online] Available:

http://www.witsetd.wits.ac.za:8080/dspace/handle/123456789/254 (Accessed 28 July 2008)

Oberholzer, S., Saayman, M., Saayman, A. \& Slabbert, દ. (2009). The socio-economic impact of Africa's oldest marine park. Paper presented at the Coastal \& Marine tourism congress (CMT), 24-25 June, Port Elizabeth, South Africa.

Phillips, A. (1998). Economic values of protected areas: guidelines for protected area managers. [Online] Available: http://www.unpei.org/PDF/policyandprogrammes/Economic-valuesProtected-areas.pdf (Accessed 18 June 2008)

Saayman, M. \& Saayman, A. (2006a). Estimating the contribution of visitor spending in the Kruger National Park to the regional economy. Journal for Sustainable Tourism, 14(1), pp. 67-81.

Saayman, M. \& Saayman, A. (2006b). Creating a framework to assess the economic contribution of national parks in South Africa: The case study of the Addo Elephant National Park. Tourism Economics, 12(4), pp. 619-633.

Saayman, A. \& Saayman, M. (2010). Regional development and national parks in South Africa: Lessons learned. Tourism Economics, to be published.

Saayman, M., Saayman, A. \& Du Plessis,C. (2005). Analysis of Spending Patterns of Visitors of the World Cup Cricket Matches. South African Journal of Sports Tourism, 10(3), pp.211-221.

Saayman, M., Saayman, A. \& Ferreira, M. (2009). The socio-economic impact of the Karoo National Park. Koedoe, 51(1), pp. 1-10.

Saayman, M., Rossouw, R. \& Saayman, A. (2012). Does Conservation Make Sense to Local Communities. Development South Africa, 29(4) Forthcoming

Samuelsson, દ. \& Stage, J. (2007). The size and distribution of the economic impacts of Namibian hunting tourism. South African Journal of Wildlife Research, 37(1), pp. 41-52.

Sandbrook, C.G. (2010). Local economic impact of different forms of nature-based tourism. Conservation letters, 3(1), pp. 21-28. 
SANParks, (2010). Survey of visitor arrivals to National Parks. Unpublished report. Pretoria: SANParks.

SANParks, (2012). Table Mountain National Park. [Online] Available: http://www.sanparks.org/parks/table_mountain. (Accessed 14 August 2012)

Scheyvens, R. (1999). Ecotourism and the empowerment of local communities. Tourism Management, 20(1), pp. 245-249.

Simelane, T.S., Kerley, G.I.H. \& Knight, M.H. (2006). Reflections on the relationships between communities and conservation areas of South Africa: the case of five South African national parks. Koedoe, 49(2), pp. 85-102.

Simpson, M.C., (2008). Community Benefit Tourism Initiatives - A conceptual oxymoron? Tourism Management, 29, pp. 1-18.

Spenceley, A. \& Goodwin, H. (2008). Nature-Based tourism and poverty alleviation: Impacts of private sector and parastatal enterprises in and around Kruger National Park, South Africa. Current Issues in Tourism, 10(2-3), pp. 255-277.

Standish, B., Boting, A., Van Zyl, H., Leiman, T. \& Trupie, J. (2004). The Economic contribution of Table Mountain National Park. Cape Town: The Graduate School of Business, University of Cape Town.

STATSSA. (2001). Census 2001 Community Profiles Database. [Online] Available: http://www.statssa.gov.za/census01/html/C2001/nteractive.asp. (Accessed 29 July 2012)

Steyn, H.S. (2000). Practical significance of the difference in means. South African Journal of Industrial Psychology, 26(3), pp. 1-3.

Streuders, C. (2008). Communication Efficacy of Karoo National Park. Unpublished masters dissertation. Potchefstroom: North-West University.

Stynes, D.J. \& White, \&.M. (2006). Reflections on measuring recreation and travel spending. Journal of Travel Research, 45, pp. 8-16.

Taylor, C.N., Gough, J.P., Warren, J. \& McClintock, N. (1999). Social and Economic Impacts of the Kahurangi National Park. Science for Conservation 119, Department of Conservation, Wellington, New Zealand.

Van der Merwe, L.H. (2008). The socio-economic impact of the Klein Karoo National Arts Festival. Unpublished masters dissertation. Potchefstroom: North-West University.

Vaughan, D.R., Farr, H. \& Slee, R.W. (2000). Estimating and interpreting the local economic benefits of visitor spending: an explanation. Leisure Studies, 19, pp. 95-118.

Venter, F.J., Naiman, R.J., Biggs, H.C. \& Pienaar, D.J. (2008). The Evolution of Conservation Management Philosophy: Science, environmental change and social adjustments in Kruger National Park. Ecosystems, 11, pp. 173-192.

West, P., Igoe, J. \& Brockington, D. (2006). Parks and People: The social impact of protected areas. The Annual Review of Anthropology, 35, (14) pp. 1-27. 
Saayman, Saayman \& Rossouw 